\title{
Morphometric and meristic characters of snow trout, Schizothorax labiatus, inhabiting the Jhelum River and its tributaries
}

\author{
Kousar Jan, Imtiaz Ahmed
}

Received - 19 February 2019/Accepted - 14 November 2020. Published online: 31 December 2020; Inland Fisheries Institute in Olsztyn, Poland Citation: Jan K., Ahmed I. 2020 - Morphometric and meristic characters of snow trout, Schizothorax labiatus, inhabiting the Jhelum River and its tributaries - Fish. Aquat. Life 28: 216-224

\begin{abstract}
Schizothorax labiatus (McClelland) is considered to be one of the most economically important fish species among Schizothorax spp. A total of twenty-four morphometric and five meristic characters were examined; 18 of the morphometric characters as percentages of total length and four characters as percentages of head length were studied. It was found that the characters of standard length, fork length, pre pelvic length, pre anal length, and pre dorsal length had the highest correlations with total length, whereas dorsal fin height followed by caudal fin height had the lowest correlations. In percentages of head length post orbital length had the highest correlation whereas snout length had the lowest correlation. Overall, the results revealed that all the morphometric characters exhibited linear relationships and depicted significantly $(\mathrm{P}<0.05)$ high degree of correlation, while the meristic characters counted were constant in all sizes of S. labiatus, indicating that they were independent of body size. The study provided basic information that will be useful for fish biologists and researchers in the future management and conservation of this fish species.
\end{abstract}

Keywords: external morphology, fish conservation, management, Schizothorax labiatus, wild population

\footnotetext{
K. Jan, I. Ahmed [ $\left.\Xi^{\circ}\right]$

Fish Nutrition Research Laboratory, Department of Zoology,

University of Kashmir, Hazratbal, Srinagar, India

e-mail: imtiazamu1@yahoo.com
}

\section{Introduction}

The subfamily Schizothoracinae is a group of specialized fishes that prevail in the torrential mountain streams of the Himalayan region. They are limited to cold regions and especially to localities with snow-fed rivers; thus, these species are generally known as snow trout. Fourteen species of Schizothorax were previously identified in the Kashmir Valley, of which only five species are presently reported in the region, including Schizothorax plagiostomus Heckel, Schizothorax curvifrons Heckel, Schizothorax esocinus Heckel, Schizothorax niger (Heckel) and Schizothorax labiatus (McClelland). Among these five species, $S$. plagiostomus, S. curvifrons, S. esocinus, and $S$. labiatus are specialized lotic forms, and $S$. niger is found chiefly in lakes. S. labiatus is know locally as chush gad and is one of the most economically important Schizothoracine fish species of Kashmir. It is also the main source of livelihood of the vast population living on the banks of the Jhelum River. This species is widely distributed throughout the Himalayan foothills and is an active freshwater fish found mostly in rivers and their tributaries. It is very 
sensitive and usually prefers cold, well-oxygenated waters that are free of pollutants.

Studies of morphometric and meristic characters are used mainly to describe fishes. Morphometric characters are the quantifiable characters obtained by measuring the external body parts of fish species (such as total length, standard length, fork length, head length, fin length, eye diameter or ratios among these measurements), while meristic characters are those that can be counted such as fin rays, gill rakers, scales, and so on (Talwar and Jhingran 1991). Taxonomic identification is regarded as the first step in studying a species (Nayman 1965, Langer et al. 2013). Various taxonomic methods are available to identify specimens, and morphometric and meristic techniques are considered to be the most reliable and simplest methods, and they are usually referred as morphological systematics (Nayman 1965). Morphological measurements, meristic counts, size, and shape provide data that support taxonomic identification (Brraich and Akhter 2015a, 2015b) and play important roles in determining taxonomic relationships (Chaklader et al. 2016). It is also reported that morphometric characters can be used effectively to study the evolutionary adaptation of species (Wainwright and Richard 1995). Assessing the well being of fish and determining possible variations among separate stocks of the same species can also be done by studying the morphometric relationships among various body parts (King 2007). Additionally, meristic characters are also useful in identifying species (Simon et al. 2010, Gogoi and Goswami 2015). Morphometric characters of fish species play important roles in determining whether there is any inconsistency among similar species from diverse geographic areas (Naeem et al. 2012).

Significant amounts of work on the morphological and morphometric characters of various fishes have been conducted in different parts of the world (Barlow 1961, Salam and Naeem 2004, Abowei and Hart 2009, Lawson and Whenu 2010, Naeem et al. 2012, Bhendarkar et al. 2014, Brraich and Akhter 2015a, 2015b, Hossen et al. 2016, Nawer et al. 2017, Pant et al. 2018, Kamboj and Kamboj 2019, Kaur et al. 2019). However, very fragmentary information is available on the morphometric and meristic characters of the Himalayan snowtrout species of this region (Bhat et al. 2010, 2013, Qadri et al. 2017, Arafat and Bakhtiyar 2020). Therefore, the present study was conducted to establish a first line of information on the morphometric and meristic characters of S. labiatus to foster better conservation and management.

\section{Materials and Methods}

\section{Study Area}

The study area selected for the present work is the famous Jhelum River of the Kashmir Valley. The Jhelum River is a river located in north-western India and eastern Pakistan. The Jhelum is an $725 \mathrm{~km}$ long river with a catchment of $33342 \mathrm{~km}^{2}$. The Jhelum River lies between $32^{\circ} 58^{\prime} 42^{\prime \prime}$ to $35^{\circ} 08^{\prime} 02^{\prime \prime} \mathrm{N}$ and $73^{\circ} 23^{\prime} 32^{\prime \prime}$ to $75^{\circ} 35^{\prime} 57^{\prime \prime} \mathrm{E}$. It originates from a splendid spring known as Chashma Verinag and is regarded as the main waterway of the Kashmir Valley. Three fish sample collection sites were selected in this river. Site I (Pampore) was upstream at the geographical coordinates of $34^{\circ} 00^{\prime} 38.35^{\prime \prime} \mathrm{N}$ and 7454'35.47" E; site II (Chattabal) was in the middle segment at $34^{\circ} 05^{\prime} 25.68^{\prime \prime} \mathrm{N}$ and $74^{\circ} 47^{\prime} 03.67^{\prime \prime} \mathrm{E}$; and

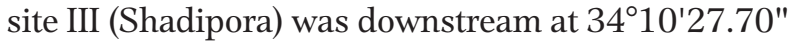
$\mathrm{N}$ and $74^{\circ} 41^{\prime} 04.41^{\prime \prime} \mathrm{E}$. The sampling sites were selected based on the occurrence of fish species at particular sites in the river and also on a survey conducted before going out to do the field work.

\section{Sampling}

A total of 94 specimens of different sizes of $S$. labiatus ranging from $16.4 \mathrm{~cm}$ to $36.4 \mathrm{~cm}$ in total length and $34.4 \mathrm{~g}$ to $423.2 \mathrm{~g}$ in body weight were collected from the sites mentioned above on the Jhelum River (Fig. 1) from January 2018 to December 2018 with the help of local fishers who deployed fishing gears such as cast nets with mesh sizes of $2 \mathrm{~cm} \times 2$ $\mathrm{cm}$ and $6 \mathrm{~cm} \times 6 \mathrm{~cm}$. 


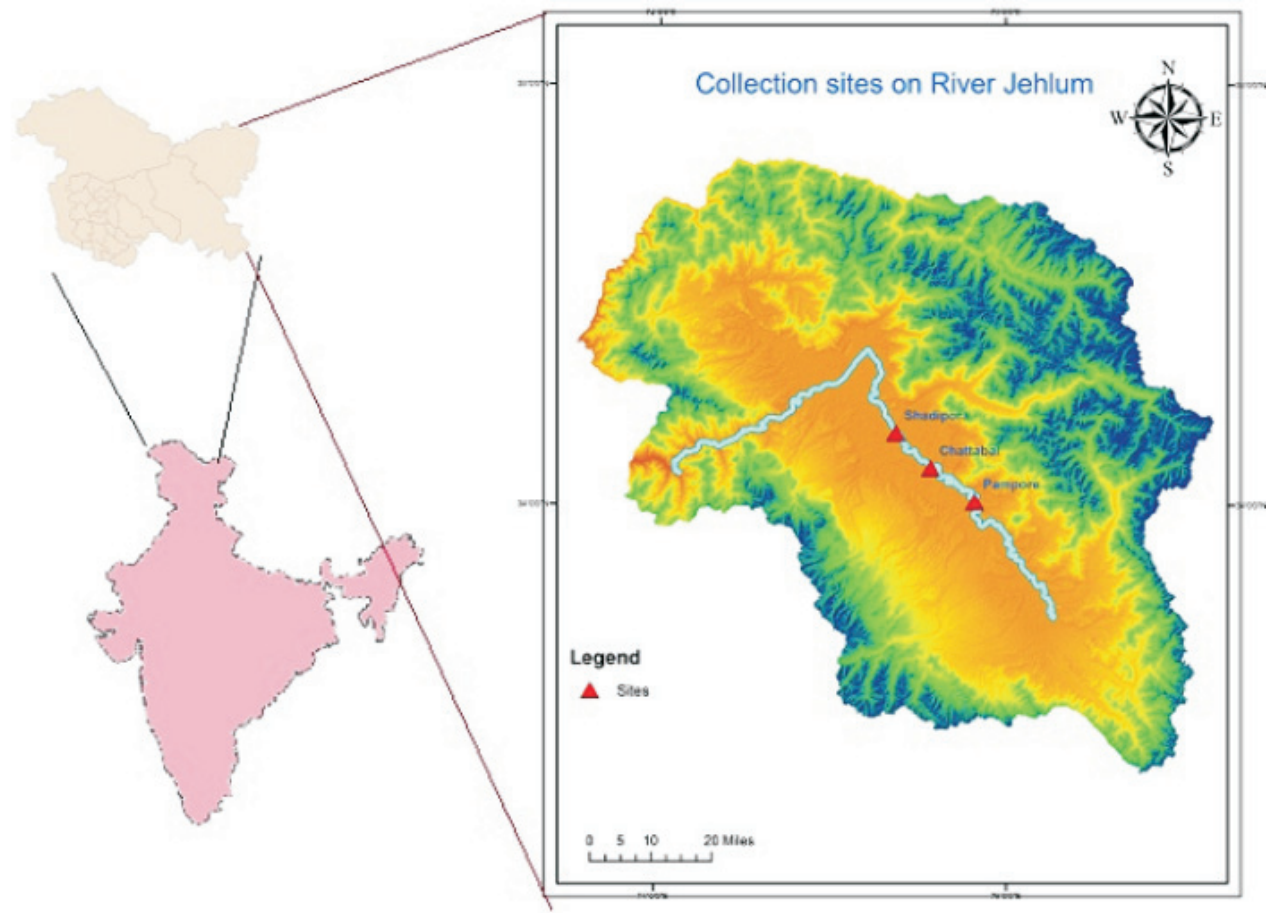

Figure 1. Sampling sites of fish collection from the Jhelum River, Kashmir, India

\section{Identification}

The specimens caught in the Jhelum River were examined and identified as S. labiatus following Day (1878), and Kullander et al. (1999). Then these fish were transferred to plastic containers containing water and transported live to the wet laboratory at the Department of Zoology, University of Kashmir. These fish were then stocked into a tank and anesthetized (MS-222 at $0.5 \mathrm{~g} \mathrm{~L}^{-1}$ of water) before measuring the morphometric and meristic characters. Dead specimens were preserved in a $10 \%$ formaldehyde solution for future reference.

\section{Morphometric and meristic study}

Twenty-four morphometric and five meristic characters were examined according to Froese and Pauly (2019). In the present study, each fish was measured to the nearest $0.01 \mathrm{~cm}$ with a digital vernier caliper, and total body weight was determined to the nearest $0.01 \mathrm{~g}$ with a digital electronic balance (Shimadzu UX320G).
The morphometric characters measured were total length, standard length, fork length, pre pectoral length, pre pelvic length, pre dorsal length, pre anal length, pectoral fin length, pectoral fin height, pelvic fin length, pelvic fin height, dorsal fin length, dorsal fin height, anal fin length, anal fin height, caudal fin length, caudal fin height, head length, snout length, eye diameter, pre orbital length, post orbital length, and maximum and minimum body depth. All the body measurements were calculated in proportion to total length except snout length, eye diameter, and pre orbital and post orbital lengths, which were calculated in proportion to head length (Holden and Raitt 1974). The meristic characters studied were the dorsal fin rays, pectoral fin rays, pelvic fin rays, anal fin rays, and caudal fin rays.

\section{Data analysis}

The data generated during the current study was subjected to statistical analysis, i.e., correlation and regression analysis using Microsoft Excel 2016. Regression analysis was mainly used to generate 
regression equations for each dependent variable to fit the straight linear equation $(\mathrm{Y}=\mathrm{a}+\mathrm{bx})$, where $\mathrm{Y}$ is the dependent variable, $a$ the intercept, $b$ the slope of the regression line and $\mathrm{x}$ the independent variable. Scatter diagrams were also plotted between log values of various morphometric parameters, and the linear regression equation was fitted using the least square method as explained by Laevastu (1965) and Snedecor and Cochran (1967). However, the values of correlation coefficient $r$ were tested at a $5 \%$ level of significance using the degree of freedom $\mathrm{df}=\mathrm{n}-1$ for all relationships, where $\mathrm{n}$ is the number of samples. Student's t-test was used to compare differences in the various morphometric parameters with regard to total length and head length.

\section{Results}

In the present study, a total of 24 morphometric characters were studied and their statistical values are presented in Tables 1 and 2. Of the 24 morphometric characters, 18 were analyzed as percentages of total fish length, while four were analyzed with regard to head length.

Eighteen characters were analyzed as proportions of total length (Table 1). Correlation analysis indicated that all the morphometric characters varied proportionally with respect to total length. The highest correlation with regard to total length was for standard length $(r=0.99)$, fork length $(r=0.99)$, pre pelvic length $(r=0.98)$, pre anal length $(r=0.97)$, and pre dorsal length $(\mathrm{r}=0.94)$, while as the lowest correlation was for dorsal fin height $(r=0.64)$ and caudal fin height $(r=0.77)$. Moreover, all the morphometric characters analyzed exhibited a linear relationship and had high degrees of correlation at $\mathrm{P}<0.05$ level of significance. Regression coefficient $b$ of various variable characters $(\mathrm{Y})$ of total length $(\mathrm{X})$ signified that the growth rate in proportion to total length was the maximum for standard length $(b=$ $1.140)$ and the minimum for pre pectoral length $(b=$ 0.743) (Table 2).
Four characters were analyzed regarding head length (Table 1). Post orbital length $(r=0.80)$ had significantly $(\mathrm{P}<0.05)$ highest correlation with head length, while snout length $(r=0.61)$ had the lowest correlation. Regression analysis revealed that with regard to head length, the maximum growth rate was noted for pre orbital length $(b=1.008)$, while the minimum growth was noted for eye diameter $(b=0.525)$ (Table 2).

The meristic measurements of S. labiatus were mainly taken by simply counting the number of fin rays of the fish examined. During the present investigation, five meristic characters were analyzed and the number of dorsal fin rays ranged from 6 to 10 with an average value of $8 \pm 0.64$, pectoral fin rays 10-19 (15 $\pm 1.74)$, pelvic fin rays $9-12(10 \pm 1.87)$, anal fin rays 5-8 (6 \pm 0.77$)$, and caudal fin rays 15-24 (19 \pm 0.51) (Table 1). Although these meristic characters showed a little difference among different specimens, the range of different numbers of fin rays in various sizes of S. labiatus indicated that meristic counts of $S$. labiatus were not dependent on fish body size.

\section{Discussion}

Knowledge of morphometric and meristic characters of fishes is regarded as one of the most vital means of evaluating the evolutionary adaptation of a species with respect to its environment, identifying fish stocks, helping in taxonomic studies, and most importantly providing information on the precise identification of particular fish species (Pant et al. 2018). Morphometric studies are employed widely as vital, cost effective tools for identifying fish stocks, including identifying subtle variations in shape. Stock identification is considered an interdisciplinary field that involves identifying self-sustaining components within natural populations (Rawat et al. 2017). Morphometric studies also help assess the growth patterns and growth rates of species, which are important for the proper exploitation and management of populations of fish species. Growth rates are commonly determined by measuring the physiological 
Table1

Minimum, maximum, range difference, mean, SD and coefficient of variation of different morphometric and meristic characters of S. labiatus $(\mathrm{n}=94)$ inhabiting the Jhelum River

\begin{tabular}{|c|c|c|c|c|c|c|}
\hline Characters & Min & Max & Range difference & Mean & SD & $\mathrm{CV}$ \\
\hline \multicolumn{7}{|c|}{ Morphometric characters } \\
\hline \multicolumn{7}{|l|}{$\%$ of total length } \\
\hline Standard length & 13.6 & 31.4 & 17.8 & 21.53 & 4.15 & 0.19 \\
\hline Fork length & 14.9 & 34.2 & 19.3 & 23.23 & 4.42 & 0.19 \\
\hline Pre pectoral length & 3.0 & 6.1 & 3.1 & 4.45 & 0.70 & 0.15 \\
\hline Pre pelvic length & 7 & 15.6 & 8.6 & 10.91 & 2.07 & 0.18 \\
\hline Pre dorsal length & 6.5 & 15.2 & 8.7 & 10.57 & 2.10 & 0.19 \\
\hline Pre anal length & 10.4 & 24.6 & 14.2 & 16.47 & 3.22 & 0.19 \\
\hline Pectoral fin length & 0.6 & 1.6 & 1.0 & 0.95 & 0.21 & 0.22 \\
\hline Pectoral fin height & 1.7 & 5.7 & 4.0 & 3.29 & 0.76 & 0.23 \\
\hline Pelvic fin length & 0.6 & 1.5 & 0.9 & 0.98 & 0.21 & 0.21 \\
\hline Pelvic fin height & 1.6 & 4.3 & 2.7 & 3.06 & 0.65 & 0.21 \\
\hline Dorsal fin length & 1.3 & 3.9 & 2.6 & 2.48 & 0.55 & 0.22 \\
\hline Dorsal fin height & 2.3 & 5.3 & 3.0 & 3.59 & 0.64 & 0.17 \\
\hline Anal fin length & 0.8 & 2.8 & 2.0 & 1.58 & 0.40 & 0.25 \\
\hline Anal fin height & 1.9 & 5.4 & 3.5 & 3.47 & 0.81 & 0.23 \\
\hline Caudal fin length & 1.5 & 4 & 2.5 & 2.43 & 0.54 & 0.22 \\
\hline Caudal fin height & 2.1 & 6.5 & 4.4 & 4.66 & 0.88 & 0.18 \\
\hline Maximum body depth & 3.6 & 9 & 5.4 & 5.64 & 1.40 & 0.24 \\
\hline Minimum body depth & 1.5 & 4 & 2.5 & 2.45 & 0.56 & 0.22 \\
\hline \multicolumn{7}{|l|}{$\%$ of head length } \\
\hline Snout length & 0.7 & 1.9 & 1.2 & 1.13 & 0.29 & 0.25 \\
\hline Eye diameter & 0.5 & 1 & 0.5 & 0.84 & 0.11 & 0.13 \\
\hline Pre orbital length & 0.8 & 2.6 & 1.8 & 1.50 & 0.37 & 0.24 \\
\hline Post orbital length & 0.8 & 3.4 & 2.6 & 2.34 & 0.44 & 0.18 \\
\hline \multicolumn{7}{|l|}{ Meristic characters } \\
\hline Dorsal fin rays & 6 & 10 & 4 & 8 & 0.64 & 0.08 \\
\hline Pectoral fin rays & 10 & 19 & 9 & 15 & 1.74 & 0.11 \\
\hline Pelvic fin rays & 9 & 12 & 3 & 10 & 1.87 & 0.18 \\
\hline Anal fin rays & 5 & 8 & 3 & 6 & 0.77 & 0.12 \\
\hline Caudal fin rays & 15 & 24 & 9 & 19 & 0.51 & 0.02 \\
\hline
\end{tabular}

features of fishes (Soliman et al. 2018). During this study, it was found that various morphometric characters were highly correlated with each other, and there was a significant $(\mathrm{P}<0.05)$ high degree of positive correlation between different morphometric parameters with respect to total length and head length. Badkur and Prashar (2015) also found positive correlations among different morphometric parameters with total length of mahseer, Tor tor
(Hamilton) in the Narmada River. Our results are comparable with findings for red tilapia, for which standard length, body depth, pectoral fin length, pelvic fin length, anal fin length, dorsal fin length, and head length correlated highly with total length, while pre orbital length and eye diameter correlated with head length (Kohinoor et al. 1995). Similar types of inferences are also reported by other authors who also found highly positive correlations among 
Table 2

Coefficient of correlation, regression equation, 95\% confidence interval of different morphometric characters of S. labiatus ( $\mathrm{n}=94)$ inhabiting the Jhelum River.

\begin{tabular}{|c|c|c|c|c|c|c|c|}
\hline \multirow[b]{2}{*}{ Characters studied } & \multirow{2}{*}{$\begin{array}{l}\text { Coefficient of } \\
\text { correlation } \\
\text { (r) }\end{array}$} & \multirow{2}{*}{$\begin{array}{l}\text { Coefficient of } \\
\text { determination } \\
\left(\mathrm{r}^{2}\right)\end{array}$} & \multirow{2}{*}{$\begin{array}{l}\text { Regression equation } \\
(\mathrm{Y}=\mathrm{a}+\mathrm{bX})\end{array}$} & \multicolumn{2}{|c|}{$\begin{array}{l}\text { 95\% Confidence } \\
\text { Interval of ' } a \text { ' }\end{array}$} & \multicolumn{2}{|c|}{$\begin{array}{l}95 \% \text { Confidence } \\
\text { Interval of 'b' }\end{array}$} \\
\hline & & & & Lower limit & Upper limit & Lower limit & Upper limit \\
\hline Standard length & 0.99 & 0.98 & $y=1.140 x-0.286$ & -0.12 & -0.05 & 0.98 & 1.14 \\
\hline Fork length & 0.99 & 0.98 & $y=1.101 x-0.235$ & -0.07 & 0.00 & 0.97 & 1.09 \\
\hline Pre pectoral length & 0.88 & 0.77 & $y=0.743 x-0.390$ & -0.50 & -0.27 & 0.66 & 0.82 \\
\hline Pre pelvic length & 0.98 & 0.96 & $y=0.994 x-0.354$ & -0.40 & -0.30 & 0.95 & 1.03 \\
\hline Pre dorsal length & 0.94 & 0.90 & $y=1.004 x-0.381$ & -0.47 & -0.28 & 0.93 & 1.07 \\
\hline Pre anal length & 0.97 & 0.95 & $y=1.015 x-0.204$ & -0.27 & -0.13 & 0.96 & 1.06 \\
\hline Pectoral fin length & 0.81 & 0.66 & $y=0.939 x-1.338$ & -1.53 & -1.14 & 0.80 & 1.07 \\
\hline Pectoral fin height & 0.82 & 0.67 & $y=1.034 x-0.934$ & -1.14 & -0.72 & 0.88 & 1.18 \\
\hline Pelvic fin length & 0.79 & 0.62 & $y=0.913 x-1.286$ & -1.49 & -1.08 & 0.76 & 1.06 \\
\hline Pelvic fin height & 0.86 & 0.74 & $y=1.029 x-0.956$ & -1.12 & -0.78 & 0.90 & 1.15 \\
\hline Dorsal fin length & 0.87 & 0.76 & $y=1.051 x-1.080$ & -1.25 & -0.91 & 0.92 & 1.17 \\
\hline Dorsal fin height & 0.64 & 0.52 & $y=0.923 x-0.318$ & -0.52 & -0.10 & 0.71 & 1.02 \\
\hline Anal fin length & 0.88 & 0.77 & $y=0.960 x-1.499$ & -1.68 & -1.31 & 0.90 & 1.04 \\
\hline Anal fin height & 0.88 & 0.78 & $y=1.073 x-1.034$ & -1.20 & -0.86 & 1.00 & 1.14 \\
\hline Caudal fin length & 0.85 & 0.73 & $y=0.996 x-1.011$ & -1.18 & -0.83 & 0.87 & 1.12 \\
\hline Caudal fin height & 0.77 & 0.60 & $y=0.817 x-0.476$ & -0.66 & -0.28 & 0.68 & 0.95 \\
\hline Maximum body depth & 0.84 & 0.71 & $y=1.068 x-0.747$ & -0.94 & -0.55 & 0.92 & 1.20 \\
\hline Minimum body depth & 0.84 & 0.71 & $y=1.014 x-1.032$ & -1.21 & -0.84 & 0.88 & 1.14 \\
\hline Snout length & 0.61 & 0.37 & $y=0.823 x-0.473$ & -0.61 & -0.33 & 0.60 & 1.04 \\
\hline Eye diameter & 0.64 & 0.41 & $y=0.525 x-0.409$ & -0.48 & -0.32 & 0.39 & 0.65 \\
\hline Pre orbital length & 0.75 & 0.56 & $y=1.008 x-0.465$ & -0.58 & -0.34 & 0.82 & 1.19 \\
\hline Post orbital length & 0.80 & 0.65 & $y=0.835 x-0.160$ & -0.23 & -0.08 & 0.70 & 0.96 \\
\hline
\end{tabular}

various morphometric characters (Johal et al. 1994, Bhatt 1997, Negi and Negi 2010, Shah et al. 2011, Naeem et al. 2012, Langer et al. 2013, Brraich and Akhter 2015a, 2015b, Hossen et al. 2016, Qadri et al. 2017, Pant et al. 2018, Kamboj and Kamboj 2019, Kaur et al. 2019, Arafat and Bakhtiyar 2020). In the present study, the highest correlations with total length were with standard length and fork length, which concurs with findings of other authors who analyzed different fish species like Tor putitora (Hamilton) (Johal et al. 1994), Mystus gulio (Hamilton) (Begum et al. 2008), Schizothorax spp. (Bhat et al. 2010), Schizothorax richardsonii (Gray) (Negi and Negi 2010), Onchorhynchus mykiss (Walbaum)
(Shah et al. 2011), Rastrelliger kanagurta (Cuvier) (Bhendarkar et al. 2014), Botia birdi Chaudhuri (Sharma et al. 2014), S. curvifrons (Qadri et al. 2017), Hypophthalmichthys molitrix (Val.) (Pant et al. 2018), and S. labiatus (Arafat and Bakhtiyar 2020). However, the lowest correlations were with dorsal and caudal fin lengths, which was similar to reports regarding fish species like H. molitrix (Pant et al. 2018) and S. labiatus (Arafat and Bakhtiyar 2020). In proportion to head length, there was a significant $(\mathrm{P}<0.05)$, maximum correlation with post orbital length, which concurred with results reported by other authors in different fish species like Nandus nandus (Hamilton) (Goswami and Dasgupta 2007), 
S. richardsonii (Negi and Negi 2010), B. birdi (Sharma et al. 2014), and Labeo rohita (Hamilton) (Kaur et al. 2019), while the minimum correlation was for snout length, which concurred with findings reported for Leiognathus splendens (Cuvier) (Gulati and Acharya 2001) and Gonialosa manmina (Hamilton) (Masud and Singh 2018).

During the current study, it was also noted that in proportion to total length, the maximum growth was calculated for standard length, while as the minimum growth was noted for pre pectoral length, which was revealed by regression analysis. Analogous results were noted in a similar kind of regression analysis done on $S$. plagiostomus from the Lidder River in the Kashmir Valley in which maximum growth in proportion to total length was calculated for standard length and minimum growth was noted for pre pectoral length, and in S. esocinus maximum growth was noted for standard length and minimum for maximum body depth (Bhat et al. 2013). Various authors (Johal et al. 2003, Alam et al. 2013, Sharma et al. 2014, Arafat and Bakhtiyar 2020) reported comparable results in equivalent types of analyses.

Meristic characters include countable, repeated structures that permit evaluating the class and species of fishes (Soliman et al. 2018). In the present study, it was found that the range of values of the meristic characters studied was well within the reported ranges of other authors who conducted research on different fish species like B. birdi (Sharma et al. 2014), Crossocheilus latius (Hamilton) (Brraich and Akhter 2015b), and Garra gotyla (Gray) (Brraich and Akhter 2015a). Moreover, these characters were somewhat constant in all groups of fishes from different length groups and did not vary with increases in total weight or total length. Our results from the current study are in agreement with the findings of other authors who also found that meristic characters remain independent of body size and weight (Zafar et al. 2002, De Silva and Liyanage 2010, Hazharika et al. 2011, Langer et al. 2013, Safi et al. 2014, Gogoi and Goswami 2015, Soliman et al. 2018). In contrast to these, variations in meristic characters were also reported by a number of authors analyzing different fish species (Al-Hassan 1987, Watanabe 1998, Jaiswar et al. 2004, Koshy et al. 2008, Brraich and Akhter 2015a, 2015b). Variations reported for meristic characters can be caused by many factors including temperature (Al-Hassan 1987, Sfakianakis et al. 2011), genetics (Yousefian 2011), nutrient availability, and seasonal variations.

\section{Conclusion}

The highest correlations to total length were for standard length, fork length, pre pelvic length, pre anal length, and pre dorsal length, while the lowest correlations were for dorsal fin height and caudal fin height. Post orbital length had the highest correlation with head length, while the lowest correlation was for snout length. All the morphometric characters studied exhibited linear relationships and significantly high degrees of correlation. Therefore, this suggested that most of the morphometric characters analyzed in the present study exhibited direct proportional increases to each other. Moreover, the five meristic characters analyzed showed little difference among the different specimens of fish, which indicated that the meristic counts were generally independent of fish body size. The data generated in the present study will be useful for developing strategies for establishing better management and conservation programs for this fish species.

Acknowledgments. Imtiaz Ahmed is extremely grateful to the Head of the Department of Zoology for providing the necessary laboratory facilities and would also like to recognize the Department of Science and Technology (DST), the Government of India, New Delhi, for providing financial assistance as a DST-INSPIRE fellowship to Kousar Jan, one of the authors.

Author contributions. K.J. collected the materials and analyzed the data, I.A. designed the study and the concept and drafted and revised the manuscript.

ORCID ID

Imtiaz Ahmed (iD https://orcid.org/0000-0003-4821-1707 


\section{References}

Abowei J.F.N., Hart A.I. 2009 - Some morphometric parameters of ten finfish species from the Lower Nun River, Niger Delta, Nigeria - Res. J. Biol. Sci. 4: 282-288.

Alam M.M., Jahan S.N., Hussain M. A., De M., Goutham-Bharathi M.P., Magalhaes A.B., Mazlan A.G., Simon K.D. 2013 - Length-length relationship, length-weight relationship and condition factor of freshwater fish species of Bangladesh - AACL Bioflux 6: 498-509.

Al-Hassan L.A.J. 1987 - Variations in meristic characters of Nematalosa nasus from Iraqi and Kuwaiti waters Japan. J. Ichthyol. 33: 422-425.

Arafat M.Y., Bakhtiyar Y. 2020 - Morphometric Attributes and their Controlling Elements in Himalayan Snow Trout, Schizothorax labiatus inhabiting Vishav Stream of South Kashmir, India - J. Ecophysiol. Occup. Health. 20: 1-7.

Badkur R., Prashar A. 2015 - Morphometric approach towards growth performance of Mahseer (Tor tor) in River Narmada near Hoshangabad (M.P) - Indian J. Pharm. Biol. Res. 3: 66-72.

Barlow G.W. 1961 - Causes and significance of morphological variation in fishes - Syst. Zool. 10: 105-117.

Begum M., Al Mamun A., Islam M.L., Alam M.J. 2008 Morphometric characters and their relationship in estuarine catfish - J. Bangladesh Agril. Univ. 6: 349-353.

Bhat F.A., Balkhi M.H., Najar A.M., Yousuf A.R. 2013 - Distribution pattern, density and morphometric characteristics of Schizothoracines (snow trouts) in Lidder River, Kashmir - The Biosean 8: 363-369.

Bhat F.A., Yousuf A.R., Balkhi M.H., Mahdi M.D., Shah F.A. 2010 - Length-weight relationship and morphometric characteristics of Schizothorax spp. in the River Lidder of Kashmir - Indian J. Fish. 57: 73-76.

Bhatt J.P. 1997 - Studies on some aspects of habitat ecology of the Mahseer Tor putitora (Ham.) from foothill-stretch of Gangain relation to altered ecological conditions - $\mathrm{PhD}$ Thesis, HNB Garhwal University, Srinagar (Garhwal).

Bhendarkar M.P., Naik S.D., Ramteke M.H., Raut S.M., Swain S. 2014 - Morphometric and meristic studies of Indian Mackerel, Rastrelliger kanagurta (Cuvier, 1817) off Southern Coast of Maharashtra, India - Eco. Env. Cons. 20: 1705-1708.

Brraich O.S., Akhter S. 2015a - Morphometric characters and meristic counts of a fish, Garra gotyla gotyla (Gray) from Ranjit Sagar Wetland, situated in the Himalayan foothills, India - Int. Res. J. Biol. Sci. 4: 66-72.

Brraich O.S., Akhter S. 2015b - Morphometric characters and meristic counts of a fish, Crossocheilus latius latius (Hamilton-Buchanan) from Ranjit Sagar Wetland, India - Int. J. Fish. Aquat. Stud. 2: 260-265.

Chaklader M.R., Siddik M.A.B., Nahar A., Hanif M.A., Alam M.J., Mahmud S. 2016 - Morphometric parameters and allometric growth in paradise threadfin Polynemus paradiseus (Linnaeus, 1758) from a coastal river of Bangladesh - J. Aquac. Res. Dev. 7: 417.

Day F. 1878 - The fishes of India, being a natural history of fishes known to inhabit the seas and fresh-waters of India, Burma and Ceylon - Quaritsch, London.

De Silva M.P.K.S.K., Liyanage N.P.P. 2010 - A multivariate approach for developing a dichotomous key for identification and differentiation of Puntius (Osteichthyes: Cyprinidae) species in Sri Lanka - J. Natl. Sci. Found. Sri. 38: 15-27.

Froese R., Pauly D. 2019 - FishBase - World Wide Web electronic publication. www.fishbase.org, version (12/2019).

Gogoi R., Goswami U.C. 2015 - Morphometric and meristic study of Amblypharyngodon mola (Ham-Buch) from different habitats of Assam - Ann. Biol. Res. 6: 10-14.

Goswami S.O.M.A., Dasgupta M. 2007 - Analysis of the morphometric and meristic characters of the fish Nandus nandus (Hamilton) from the new alluvial zone of West Bengal - Rec. Zool. Surv. India. 107: 81-90.

Gulati D., Acharya P. 2001 - Study on the morphometric and meristic characteristics of splendid silver belly Leiognathus splendens (Cuvier) from Bombay coast - J. Indian Fish. Assoc. 28: 37-45.

Hazarika A., Borah U., Bordoloi L. 2011 - Studies on morphometric measurements and meristic counts of Hill Trout (Barilius bendelisis, Hamilton) from the river Buroi at the boundary areas of Assam and Arunachal Pradesh, India - Indian J. Fundam. Appl. Life Sci. 1: 194-198.

Holden M.J., Raitt D.F.S. 1974 - Manual of fisheries science. Part 2. Methods of resource investigation and their application - FAO fisheries technical paper No. 115, Rev. 1. FAO, Rome, Italy, $214 \mathrm{p}$.

Hossen M.A., Hossain M.Y., Pramanik M.N.U., Nawer F., Khatun D., Parvin M.F., Rahman M.M. 2016 - Morphological characters of Botia lohachata - J. Coast. Life. Med. 4: 689-692.

Jaiswar A.K., Parida P.K., Chakraborty S.K., Palaniswamy R. 2004 - Morphometry and length-weight relationship of obtuse barracuda Sphyraena obtusata (Cuvier) (Teleostomi/Actinopterygii/Sphyraenidae) from Bombay waters, west coast of India - Indian J. Mar. Sci. 33: 307-309.

Johal M.S., Negi R. K., Negi T. 2003 - Age and growth of golden mahseer Tor putitora from Pong reservoir, Himachal Pradesh, India - Him. J. Env. Zools. 17: 17-29.

Johal M.S., Tandon K.K., Sandhu G.S. 1994 - Mahseer in Lacustrine Waters, Gobindsagar Reservoir. Morphometry of Tor putitora - In: Mahseer the Game Fish (Ed.) P. Nautiyal, Jagdamba Prakashan Publisher, Dehradun, Rachna, Srinagar, Garhwal: 67-85.

Kamboj N., Kamboj V. 2019 - Morphometric and meristic study of four freshwater fish species of river Ganga Indian J. Anim. Sci. 89: 470-473. 
Kaur V., Ana Y., Heer B.K. 2019 - Morphometric analysis of fish, Labeo rohita (Hamilton) from pond near Kalayat, Kaithal, Haryana India - Int. J. Fish. Aquat. Stud. 7: 299-306.

King M. 2007 - Fisheries Biology. Assessment and management (2nd Ed.) - Blackwell Scientific Publications, Oxford $381 \mathrm{p}$.

Kohinoor A.H.M., Saha N.C., Akhteruzzaman M., Shah M.S., Mahata S.C. 1995 - Morphometric characters and their relationship in Red tilapia (mutant Oreochromis mossambicus $\times$ Oreochromis niloticus) - Bangladesh J. Fish. 15: 129-131.

Koshy B.E., Selvaraj O., Sekaran M. 2008 - Variation in meristic characters of four strains of Malaysian Freshwater Angelfish Pterophyllum scalare (L.) - Malaysian J. Sci. 27: 69-73.

Kullander S.O., Fang. F., Delling B., Ahlander E. 1999 - The fishes of the Kashmir Valley - In: River Jhelum, Kashmir Valley. Impact on the aquatic environment (Ed.) L. Nyman, Swedmar, Goteborg, Sweden: 99-167.

Laevastu T. 1965 - Manual of methods in fisheries biology. Research on fish stocks - FAO Manuals in Fisheries Science 4: 1-51.

Langer S., Tripathi N.K., Khajuria B. 2013 - Morphometric and meristic study of golden mahseer (Tor putitora) from Jhajjar Stream (JandK), India - Res. J. Anim. Vet. Fish. Sci. 1: 1-4.

Lawson E.O., Whenu O.O. 2010 - Morphometric measurements and meristic counts in mudskipper (Periophthalmus papilio) from mangrove swamps of Lagos lagoon, Nigeria - J. Appl. Biosci. 34: 2166-2172.

Masud S., Singh K.P. 2018 - Food and feeding habit of Gonialosa manmina (Ham.) from the River Yamuna, Allahabad, India - Fish. Aquacult. J. 9: 1-6.

Naeem M., Zuberi A., Khan N.A., Rasool S.A., Ismail H.F., Qamar A. 2012 - Some morphometric relationship traits of Labeo bata (Hamilton, 1822) from Head Panjnad, Pakistan - Afr. J. Biotechnol. 11: 15465-15468.

Nawer F., Hossain M.Y., Hossen M.A., Khatun D., Parvin M.F., Ohtomi J., Islam M.A. 2017 - Morphometric relationships of the endangered Ticto barb Pethia ticto (Hamilton, 1822) in the Ganges River (NW Bangladesh) through multi-linear dimensions - Jordan J. Biol. Sci. 10: 199-203.

Nayman W.H. 1965 - Growth and ecology of fish population - J. Anim. Ecol. 20: 201-219.

Negi R.K., Negi T. 2010 - Analysis of morphometric characters of Schizothorax richardsonii (Gray, 1832) from the Uttarkashi district of Uttarakhand state, India - J. Biol. Sci. 10: 536-540.

Pant B., Kaur R., Lohani V., Ram R.N. 2018 - Morphometric characteristics of silver carp (Hypophthalmichthys molitrix) under captive conditions - Pharma Innov. J. 7:17-20.

Qadri S., Shah T.H., Balkhi M.H., Bhat B.A., Bhat F.A., Najar A.M., Asmi O.A., Farooq I., Alia S. 2017 -
Morphometrics and length-weight relationship of Schizothorax curvifrons Heckel 1838 in River Jhelum, Kashmir, India - Indian J. Anim. Res. 51: 453-458.

Rawat S., Benakappa S., Kumar J., Naik K., Pandey G., Pema C.W. 2017 - Identification of fish stocks based on truss morphometric: A review - J. Fish. Life. Sci. 2: 9-14.

Safi A., Khan M.A., Khan M.Z. 2014 - Study of some morphometric and meristic characters of striped piggy fish, Pomadasys stridens (Forsskal, 1775) from Karachi Coast, Pakistan - J. Zool. St. 1: 1-6.

Salam A., Naeem M. 2004 - Some morphometric studies of common carp Cyprinus carpio in relation to body size, from Islamabad, Pakistan - Sindh Univ. Res. J. 36: 21-48.

Sfakianakis D.G., Leris I., Laggis A., Kentouri M. 2011 - The effect of rearing temperature on body shape and meristic characters in zebrafish (Danio rerio) juveniles - Environ. Biol. Fishes 92: 197.

Shah T.H., Balkhi M.H., Najar A.M., Asimi O.A. 2011 Morphometry, length-weight relationship and condition factor of farmed female rainbow trout (Oncorhynchus mykiss Walbaum) in Kashmir - Indian J. Fish. 58: 51-56.

Sharma N.K., Mir J.I., Pandey N., Singh R. 2014 Morphometric and Meristic Characteristics of Birdi Loach, Botia birdi (Chaudhuri, 1909) from a Tributary of Indus Basin, Jammu and Kashmir, India - World J. Fish Mar. Sci. 6: 262-266.

Simon K.D., Bakar Y., Temple S.E., Mazlan A.G. 2010 Morphometric and meristic variation in two congeneric archer fishes Toxotes chatareus (Hamilton 1822) and Toxotes jaculatrix (Pallas 1767) inhabiting Malaysian coastal waters - J. Zhejiang Univ. Sci. B 11: 871-879.

Snedecor G.W., Cochran, W.G. 1967 - Statistical Methods (6th Ed.) - Oxford and IBH Publishing Co., New Delhi, $593 \mathrm{p}$.

Soliman F.M., Mehanna S.F., Soliman H.A., Baker T.S. 2018 - Meristic and morphometric characteristics of five-lined snapper, Lutjanus quinquelineatus (Bloch, 1790) from the Red Sea, Egypt - Egyptian J. Aquat. Biol. Fish. 22: 41-48.

Talwar P.K., Jhingran A.G. 1991 - Inland fishes of India and Adjacent Countries - Oxford and IBH Publishing Co.Pvt. Ltd. New Delhi, Bombay, Calcutta 402 p.

Wainwright P.C., Richard B.A. 1995 - Predicting patterns of prey use from morphology of fishes - Environ. Biol. Fishes 44: 97-113.

Watanabe K. 1998 - Meristic variation in the endangered bagrid catfish, Pseudobagrus ichikawai - Ichthyol. Res. 45: 99-104.

Yousefian M. 2011 - Study on morphological variation in Iran grass carp stocks - World Appl. Sci. J. 12: 1234-1239.

Zafar M., Nazir A., Akhtar N., Naqvi S.M.H.M., Zia-ur-Rehman M. 2002 - Studies on meristic counts and morphometric measurements of Mahseer (Tor putitora) from a spawning ground of Himalayan foot-hill River Korang Islamabad, Pakistan - Pak. J. Biol. Sci. 5: 733-735. 